\title{
PEDAGOGICAL PROJECT OF INTEGRATED CLASSES IN PHYSICAL EDUCATION AND ENGLISH
}

\author{
Tatyana Bashta ${ }^{1}$, Olesya Zalutskaya ${ }^{2}$ \\ ${ }^{I}$ NI TC «Erfolg», Karaganda, Kazakhstan \\ ${ }^{2}$ NI TC «Erfolg», Karaganda, Kazakhstan
}

ORCID iD: 0000-0003-3113-483X

\begin{abstract}
The pedagogical project of integrated physical education and English lessons to increase motivation for learning a foreign language and involving into a healthy lifestyle, as well as improving the physical skills of pupils representing an interdisciplinary, medium-term, sports and gaming project involving interaction and cooperation of teachers aimed at developing physical abilities and increasing interest in learning English. A feature of the pedagogical project is the integration of two types of activities: doing sports and learning a foreign language. The relevance of the chosen topic is to develop children's physical skills and interest in learning a foreign language, as well as to involve parents in joint motor activity and speech activity with the child.
\end{abstract}

\section{INTRODUCTION}

In the modern world, the education system is being modernized to improve the quality of education, its accessibility for supporting and developing the talent of each child, saving his health. Physical education is not only a means of developing physical qualities of a child and strengthening his health but it is also an important component and a means of spiritual, moral, aesthetic education of a preschooler [Osokina, 1973]. The socio-economic changes taking place in our country in recent years have led to a decisive revision of the place and role of foreign languages in the life of society. Therefore, it is important to carry out ongoing teaching of foreign languages to children, starting from kindergarten. In this regard, there is a question of an integrated lesson in English and physical culture, since the most effective educational tasks are solved when the teacher purposefully uses an integrative approach in the organization of the educational process.

Integrated lessons give the pupil rather broad and vivid idea of the world in which he lives, the relationship of phenomena and objects, mutual aid, the existence of various world of material and artistic culture. The main emphasis is not so much on the assimilation of certain knowledge, as on the development of imaginative thinking. It confirms the importance of using this type of activity in the practice of working with children. As you know, for preschool children, movement is a biological need of the body. It is noted that with the help of physical actions, children learn language material better. Therefore, learning a foreign language is more effective to build on the basis of motor activity and in a playful way. This pedagogical project fully corresponds to the goals and objectives of modern education [Ekzhanova, 2008].

The purpose of the project is to involve parents in joint motor activity with a child creating emotionally favorable atmosphere during the event. To develop pupil's physical skills and interest in traditions of people and country of the language being studied, to consolidate the skills of mastering of lexical units in English on the themes «Sport» and «The verbs of action», as well as to promote to creation of warm relationship in the family.

Tasks:

- Development of motor abilities (coordination, speed and endurance).

- Formation of students' speech, language, socio-cultural competence.

- Formation of a sustained interest in physical education.

- Teaching the ability to tell what you can (can't) do using a speech sample: I can't ... I can...

- Fostering to mental, moral, aesthetic and labor education. 
- The development of mind, memory, imagination, will.

- Broaden of pupils' horizons.

- Formation of basic vital motor skills and abilities.

- Formation of motivation to cognition and physical activity.

- Education of respect to the people's way of the life of the country which language being studied.

- Education of a sense of tolerance.

- Education of moral and volitional qualities.

- To hold several events together with parents and pupils.

\section{THE MAIN CONTENT OF THE PROJECT}

The work of the project was to create the script of educational activities that will help instill interest and love for learning English and physical education, expand horizons, develop memory and attention, the rapidity of reaction.

Much attention was paid to health-saving teaching methods. During the work of the project, physical education and English classes were held. The pupils not only performed physical exercises, but also got acquainted with their sounding in a foreign language. In English classes, children actively worked with the grammatical structures such as "I can ... Can you...?", also consolidated lexical units on the topic "The verbs of action" while doing physical exercises.

During the lesson pupils were given the commands in English, which are used in physical culture (align, stand still, turn right, turn left, etc.) When choosing subjects, lexical and grammatical constructions, the level of development of children, their motivation and interests, as well as correlation with curriculum for the development of cognitive abilities and speech in Russian in kindergarten are taken into account.

Motor creativity was used in PE classes. Even the simplest movements give food to children's imagination, develop creativity. Creativity is the highest component in the structure of personality. Motor creativity reveals to the child the motor characteristics of his own body, forms the speed and ease of orientation in the infinite space of motor images, and teaches him to treat movement as a subject of game experimentation. The means of his development can be motor tasks, with the help of which children enter an imaginary situation; through body movement they learn to express their emotions and states, look for some compositions, and create new storylines, forms of movements [Keneman, 1972].

Table1. Project schedule

\begin{tabular}{|l|l|l|}
\hline Month & PE trainer & Teacher of additional education (English) \\
\hline September & Preparation of documents for the implementation of a pedagogical project. \\
\hline October & \multicolumn{1}{|c|}{$\begin{array}{l}\text { Conducting IFA in English in pre-school } \\
\text { groups. Introduction and consolidation on the } \\
\text { topic "Sports", "The verbs of action". } \\
\text { Familiarization of children with the traditions } \\
\text { of the country of the language being studied. }\end{array}$} \\
\hline November & $\begin{array}{l}\text { Conducting of integrated classes in selected age groups within the project } \\
\text { framework. Conducting of Leisure activities together with parents within the } \\
\text { project framework. }\end{array}$ \\
\hline December & \begin{tabular}{l} 
Summing up the results of the project. \\
\hline
\end{tabular}
\end{tabular}


The joint creative work of a teacher of additional education in English and PE trainer, up bringers and parents can be of great benefit for the realization of the goals and objectives of training. The classes were designed for pre-school children at NI TC "ERFOLG".

Teachers used the following types of work:

1. Working on pronunciation: rhymes, poems, songs.

2. Working with a toy: dialogue with a toy, description of a toy.

3. Learning poems and songs by heart.

4. Outdoor games.

5. Quiet games.

6. Creative games.

7. Acting out of situational dialogues.

8. Consolidation of the learnt material within the framework of the topic being studied.

9. Physical culture and wellness work in the day mode - morning hygienic gymnastics, outdoor games and physical exercises on walks (morning and evening), physical culture minute.

4. Active recreation - physical culture leisure, physical culture holidays, hiking, excursions, walking along the route (the simplest tourism), health days.

5. Work with the family.

Special educational cartoons for preschoolers are used as additional material. This type of work always causes a positive attitude of children and is a means of increasing motivation in language learning. For a more visual perception, the presentation of Microsoft Power Point is demonstrated. The dominant activity is gaming activity. In the process of educating motor actions, taking into account the psychophysiological features of the child's development, relying on his capabilities, an adult consistently puts new motor programs in front of him. Specifically, this is expressed in the gradually increasing requirements of the physical education program aimed at the formation of motor skills and physical qualities.

In the process of learning to move, a child develops physical and mental abilities, spiritual and moral qualities of personality, aesthetic feelings; bodily reflection, awareness, purposefulness and organization of motor actions, initiative and desire for creativity are brought up; memory, imagination, fantasy are developed; educating a child's body culture, the teacher simultaneously improves his spiritual culture [Osokina, 1973].

Pedagogical expediency consists of creating favorable conditions for the maximum disclosure of the individual and creative potential of children, the identification and development of their linguistic and special abilities for the purpose of further self-determination in the educational and cognitive space of additional education systems [Sazhina, 2007].

Physical activity contributes to the normal development of the central nervous system, improving memory, learning processes, normalization of the emotional sphere, improving sleep, increasing opportunities not only in physical, but also in mental activity. To increase muscle activity, physical exercises are necessary to improve motor processes and skills, posture, and prevent the development of flat feet. Mastering movements has a good effect on the development of a child's speech. The understanding of adult speech improves, the vocabulary of active speech expands [Osokina, 1973].

\section{Project resources:}

Temporary: Project duration: medium-term (4 months).

Normative - legal:

- The main provisions of the «Declaration of Human Rights» adopted by the UN General Assembly.

- The main provisions of the «Convention on the Rights of the Child» adopted by the UN General Assembly.

- The Law of the Republic of Kazakhstan "About Education".

- The State mandatory standard of Preschool Education and Training (hereinafter referred to as the Standard) (Order of the Ministry of Education and Science of the Republic of Kazakhstan dated October 31, 2018 No. 604). 
- Standard curriculum of preschool education and Training No. 557 dated December 20, 2012 (with amendments and additions dated October 10, 2018 No. 556).

- Standard curriculum of preschool education and Training (hereinafter referred to as the Program) (Order of the Ministry of Education and Science of the Republic of Kazakhstan dated August 12, 2016 No. 499).

- Standard Rules for the activities of preschool organizations (Order of the Ministry of Education and Science of the Republic of Kazakhstan dated October 30, 2018 No. 595).

- The standard defines the requirements for the level of preparation of preschool children, the content of preschool education and training and the maximum amount of educational load.

- The content of preschool education and training is based on the educational areas of "Health", "Communication", "Cognition", "Creativity", "Society", focused on the versatile development of children, taking into account their age and individual characteristics and integration of the content of educational areas.

Educational field "Health".

The educational field "Health" is aimed at developing physical qualities, improving the basic types of movements, forming motor skills, organizing and conducting various outdoor games, performing sports exercises (sledding, skiing, cycling, swimming); acquaintance with the elements of sports games (football, basketball, badminton, etc.).

The content of the educational field "Health" is aimed at protecting and strengthening the health of the child; the formation of safe behavior skills at home, on the street, in nature and enriching the motor experience of children through the improvement of basic movements, improving the needs of pupils for motor activity, using creative, cognitive and speech abilities. In the context of the implementation of new normative and substantive approaches, the kindergarten has set targets that imply openness, close cooperation and interaction with parents. Parents are active participants in the educational process, participants in all projects, regardless of what activity dominates them, and not just bystanders [The State mandatory standard of Preschool Education and Training, 2018].

Organized educational activities in the educational field "Health":

- Physical education.

- Fundamentals of safe behavior.

- The message of the President of the Republic of Kazakhstan, Kassym-Jomart Tokayev,

"Constructive public dialogue is the basis of stability and prosperity of Kazakhstan" speaks about strengthening the health of the nation. In particular, the document notes: "It is important to develop mass sports among all age groups of the population. It is necessary to ensure maximum accessibility of sports infrastructure for children. The development of mass physical culture should become a pyramid, at the top of which there will be new champions, and at its base we will get healthy, active youth and, ultimately, a strong nation".

- The concept of development of physical culture and sports of the Republic of Kazakhstan until 2025, Astana 2016.

Informational:

- publication of lesson materials,

- outdoor leisure activities.

Personnel:

- Methodist,

- PE trainer,

- teacher of additional education in English,

- up bringers.

Materially-technical:

- visual aids, special educational cartoons;

- English program «With English to Future» (2016),

- handout,

- multimedia projector, Microsoft Power Point presentation; laptop, camera; 
- 2 sets of clothes,

- 2 brooms, 4 small baskets;

- 2 sets of vegetables, 2 small hoops;

- 6 cones, 2 pots;

- music center, songs in English.

Partners:

- up bringers,

- parents,

- pupils,

Target audience:

The project is designed for students of the preschool groups of the Training Center. The educational process is based on the latest educational and methodological complexes, specially selected taking into account the age and individual abilities of pupils.

Project implementation plan:

Preparatory stage (September):

- Defining the topic, goals and objectives, the content of the project, forecasting the result.

- Preparation of documentation for the implementation of a pedagogical project.

- Development of a scenario of educational activities on the project topic.

- Study of methodological literature on this topic of the project.

The main stage of the project (October-early November):

- Preparation of a long-term plan of events.

- Inclusion of activities in the process of educational activities.

- Self-analysis of the educational activities.

Table 2. The plan of activities for leisure activities within the framework of the project

\begin{tabular}{|l|l|l|}
\hline $\begin{array}{l}\text { The days } \\
\text { of the week }\end{array}$ & Groups & Time \\
\hline Monday & $1^{\text {st }}$ group & $9.15-9.45$ \\
& $2^{\text {nd }}$ group & $9.50-10.20$ \\
\hline Tuesday & $4^{\text {th }}$ group & $9.15-9.45$ \\
& $3^{\text {rd }}$ group & $9.50-10.20$ \\
\hline Wednesday & $8^{\text {th }}$ group & $9.15-9.45$ \\
& $5^{\text {th }}$ group & $9.50-10.20$ \\
\hline Friday & $6^{\text {th }}$ group & $9.15-9.45$ \\
& $7^{\text {th }}$ group & $9.50-10.20$ \\
\hline
\end{tabular}

Final stage (December):

- Summing up the project.

- Awarding of participants with certificates.

Expected results and social impact:

- Increasing of cognitive interest in English, developing of motivation to study a foreign language.

- Education and personal development through familiarization with the culture of the Motherland and English-speaking countries.

- Development of linguistic abilities of preschoolers through the activation of their physical activity.

- Education of respect for the lifestyle of the people of the language country being studied, a sense of tolerance. 


\section{CONCLUSION}

Analyzing the work done, we can draw conclusions:

- The theme of the developed project was chosen taking into account the age characteristics of older children.

- There was a positive reaction and emotional response of children to the integration of physical culture and language learning.

- Children's speech activity has increased, attention has become more focused, memory has improved.

- We believe that good results of teachers' interaction have been achieved.

We would like to note that classes for the project can be changed depending on the interests of the students and their age group.

The implementation of the project provided emotional comfort and positive psychological well-being of the child in the process of communicating with peers and the teacher, ensured the social and emotional well-being of the preschooler.

The application of the project also had a positive impact on the development of professional and creative potential of teachers. The pedagogical project allowed to develop their professional practical skills, to give the learning process a non-standard, creative image.

Preschool age is especially favorable for the beginning of learning a foreign language: children of this age are particularly sensitive to linguistic phenomena; they have an interest in understanding their speech experience, the "secrets" of the language. They easily and firmly memorize a small amount of language material and reproduce it well.

Through a foreign language, the student learns the culture, holidays and traditions of the people who speak it. The process of studying foreign culture goes from the private (language structures) to the general (knowledge and understanding of culture). In the future, in our teaching activities, we plan to introduce integrated classes in this area.

\section{REFERENCES}

Ekzhanova, E.A., \& Reznikova, E.V. (2008). Osnovy integrirovannogo obucheniia i vospitaniia [The basics of integrated education and upbrining]. Moscow: Drofa.

Flood, J. (2005). Methods of research on teaching the English language arts: the methodology chapters from the handbook of research on teaching the English language arts (2nd ed.). Mahwah, New Jersey.

Galskova, N.D., \& Gez, N.I. (2006). Teoria obuchenia inostrannym iazikam. Lingvodidaktika $i$ metodika [Theory of teaching foreign languages. Linguodidactics and methods]. M.: Izdatelskii tsentr «Akademiia».

Keneman, A.V., \& Huhlaeva, D.V. (1972). Teoria $i$ metodika fizicheskogo vospitaniia detey doshkolnogo vozrasta [Theory and methodology of physical education of preschool children]. Moscow: Prosveschenie.

Minster of education and science of Republic of Kazakhstan (2018). The State mandatory standard of Preschool Education and Training. (No. 604). Kazakhstan. Nur-Sultan.

Osokina, T.I. (1973). Fizicheskaia kultura $v$ detskom sadu [Phisical education in kindergarten] . Moscow: Prosveschenie.

Sazhina, S.D. (2007). Tehnologiia integrirovannogo zaniatiia $v$ doshkoljnom obrazovateljnom uchrezhdenii [Technology of integrated classes in a preschool educational institution]. Syktyvkar: Syktyvkar pedagogical college №2.

VanDyke, J. (2012). Integrated teaching methods. Prezi. https://prezi.com/3irpgi7jpuxi/integratedteaching-methods/ 